\title{
Desain Kapal Motor Penyeberangan dengan Sistem Penggerak Hibrida untuk Rute Ujung Surabaya-Kamal Bangkalan
}

\author{
Dwi Agustin, Hesty Anita Kurniawati \\ Departemen Teknik Perkapalan, Fakultas Teknologi Kelautan, Institut Teknologi Sepuluh Nopember \\ (ITS) \\ e-mail:tita@na.its.ac.id
}

\begin{abstract}
Abstrak-Kondisi Penyeberangan Ujung-Kamal yang semakin sepi penumpang membuat Pengusaha ASDP terus merugi hingga berniat menutup jalur penyeberangan ini. Salah satu faktor penyebab adalah tingginya biaya operasional untuk bahan bakar BBM. Selain itu, Surabaya merupakan salah satu kota dengan tingkat emisi gas buang yang tinggi dari kendaraan bermotor dengan bahan bakar BBM. Jurnal ini bermaksud memberikan solusi untuk mengurangi jumlah emisi gas buang serta bisa menghemat pemakaian bahan bakar BBM dengan memasukkan konsep kapal dengan sistem penggerak hibrida. Jenis hibrida yang digunakan adalah mesin diesel, hydrogen fuel cell, dan solar panel cell. Payload dari Kapal Motor Penyeberangan ini merupakan jumlah pengguna jasa angkutan Ujung-Kamalyang diperoleh dari PT. Angkutan Sungai Danau dan Penyeberangan (ASDP). Kemudian dari jumlah pengguna jasa angkutan dibuat gambar awal untuk menghitung payload luasan geladak (geladak penumpang dan kendaraan), sehingga didapatkan ukuran utama kapal dari layout geladak penumpang dan kendaraan. Setelah itu dilakukan perhitungan teknis berupa perhitungan berat, trim, freeboard, dan stabilitas. Ukuran utama yang didapatkan adalah Lpp $=42 \mathrm{~m} ; B=6.9 \mathrm{~m} ; \mathrm{H}=3 \mathrm{~m} ; \mathrm{T}=2 \mathrm{~m}$. Tinggi freeboard minimum sebesar $150 \mathrm{~mm}$, besarnya tonnase kapal adalah 295 GT, dan kondisi stabilitas Kapal Motor Penyeberangan memenuhi kriteria Intact Stability (IS) Code Reg. III/3.1. Biaya pembangunan kapal baru sebesar Rp 13,173,344,991.91 dengan BEP pada bulan ke-68, sehingga kapal ini layak untuk dibangun.
\end{abstract}

Kata Kunci-Emisi, Hibrida (hydrogen fuel cell, mesin diesel, dan solar panel cell), kapal motor penyeberangan, Ujung Kamal.

\section{PENDAHULUAN}

$\mathrm{K}$ OTA Surabaya merupakan salah satu dari empat kota dengan tingkat emisi gas buang yang tinggi menurut data yang dirilis oleh World Health Organization (WHO) pada tahun 2008 hingga sekarang, di mana Surabaya memiliki tingkat polusi yang jauh di atas batas aman WHO yaitu nilainya mencapai $69 \mu \mathrm{g} / \mathrm{m}^{3}$ pertahun. Menurut penelitian WHO, banyak kota besar di dunia, termasuk di Indonesia yang memiliki tingkat polusi PM10 rata-rata per tahun yang jauh melebihi batas aman yang ditetapkan organisasi kesehatan dunia ini [1]. Dari sisi akademik, PM10 adalah benda-benda partikulat yang ukurannya kurang dari 10 mikron. Bendabenda partikulat ini hampir mustahil diamati dengan mata telanjang. Manusia hanya bisa melihat benda dengan berukuran sama atau di atas 40 mikron tanpa bantuan alat seperti mikroskop.

Pada 2009 setelah Jembatan Suramadu dioperasikan, pengguna jasa Ujung-Kamal semakin sepi sehingga membuat Pengusaha ASDP ingin menutup jalur ini. Puncaknya pada 2 Maret 2016 saat tarif Suramadu sudah digratiskan untuk motor dan turun 50\% untuk mobil. Sementara Gubernur Jawa Timur menolak untuk menutup jalur penyeberangan Ujung-Kamal karena jalur ini merupakan satu-satunya jalur air yang menghubungkan Pulau Jawa dan Madura.

Untuk mengurangi polusi dan timbulnya emisi gas buang, maka dikembangkan konsep kapal hibrida antara bahan bakar alternatif non-diesel berupa hydrogen fuel cells, mesin diesel dan solar panel sebagai daya penggerak kapal. Oleh karena itu, pada Jurnal ini akan dikembangkan konsep Kapal Motor Penyeberangan dengan sistem penggerak hibrida untuk rute Ujung Surabaya-Kamal Bangkalan.

\section{TINJAUAN PUSTAKA}

\section{A. Rute Penyeberangan}

Rute penyeberangan Ujung-Kamal merupakan jalur penyeberangan antara Pulau Jawa dan Pulau Madura. Penyeberangan antar pulau ini berjarak kurang lebih $3 \mathrm{~km}$ dan bisa ditempuh dengan waktu rata-rata selama 30 menit dengan menggunakan kapal penyeberangan dengan kecepatan 10 knot.

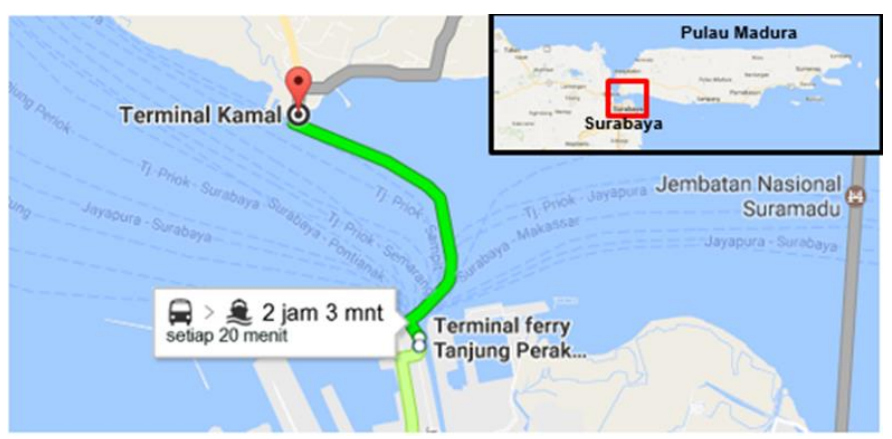

Gambar 1. Rute penyeberangan

Menurut PT. Angkutan Sungai Danau dan Penyeberangan (ASDP) Cabang Surabaya (2017), pada jalur penyeberangan Ujung Surabaya-Kamal Bangkalan pada tahun 2017 hanya ada tiga unit kapal tipe KMP yang melayani penyeberangan ini. 
Pelabuhan Ujung terletak di kawasan Pelabuhan Tanjung Perak Surabaya.

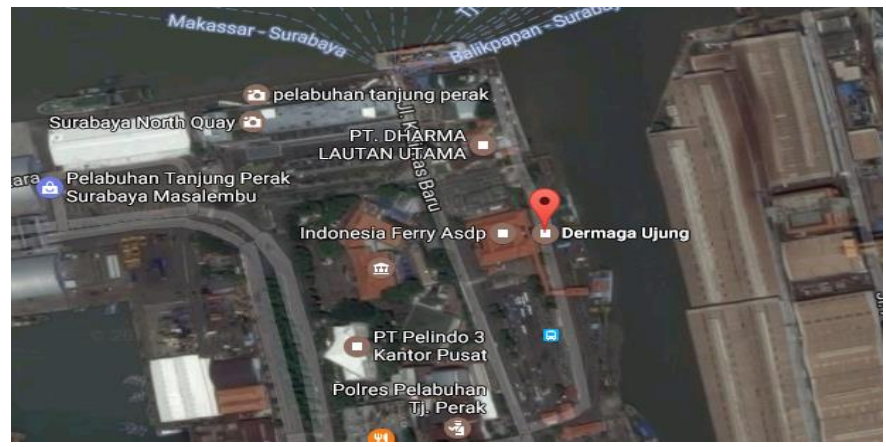

Gambar 2. Pelabuhan Ujung Surabaya

Pelabuhan ujung termasuk di dalam kawasan Pelabuhan Tanjung Perak.



Gambar 3. Pelabuhan Kamal Bangkalan

Kondisi lalu lintas penyeberangan di Pelabuhan kamal Bangkalan, Madura dapat dilihat pada Gambar 3. Pada tahun 2017 ada tiga kapal yang melayani penyeberangan di UjungKamal yaitu KMP Gajah Mada, KMP Jokotole, dan KMP Tongkol.

\section{B. Kapal Motor Penyeberangan}

Kapal Motor Penyeberangan (KMP) adalah tipe kapal yang digunakan sebagai angkutan penyeberangan antar pulau yang mengangkut kendaraan, barang, dan penumpang. Jangkauan penyeberangan kapal tipe KMP adalah dalam tujuan jarak dekat sehingga sering disebut sebagai transportasi pantai, sungai, dan danau seperti pada Gambar 4 yang diambil dari shippinglineindonesia.com [2].

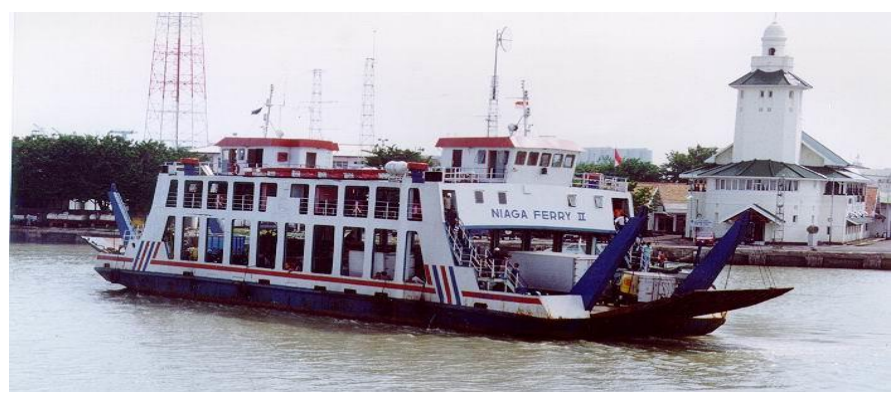

Gambar 4. Kapal Motor Penyeberangan

\section{MARPOL ANNEX VI}

Regulasi yang mengatur tentang masalah polusi yang dihasilkan oleh kapal yaitu MARPOL 73/78 oleh International Maritime Organization (IMO). MARPOL 73/78 merupakan regulasi yang bertujuan untuk mencegah atau mengurangi timbulnya polusi yang dihasilkan oleh kapal. Dalam MARPOL 73/78 terdapat ANNEX VI yang mengatur tentang pencegahan dari polusi udara yang dihasilkan kapal. Regulasi dalam ANNEX VI ini secara umum mengatur tentang:

- Menentukan batas dari emisi NOx, SOx dan Particulate Matter (PM dari kapal)

- Pelarangan emisi Ozone Depleting Substances (ODS)[3].

Emisi gas buang dari kapal telah diatur dalam Lampiran VI MARPOL 73/78 Tahun 2006 "Peraturan tentang pencegahan pencemaran udara dari kapal".Kawasan Kontrol Emisi adalah kawasan dimana diterapkan aturan khusus terkait dengan emisi dari kapal yang diperlukan untuk mencegah, mengurangi dan mengendalikan pencemaran udara dari NOx atau SOx dan bahan lainnya atau ketiga tipe emisi di atas dan keberadaannya berdampak bagi kesehatan manusia dan lingkungan [4].

\section{Sistem Hibrida}

Kapal penyeberangan dengan sistem penggerak hibrida ini menggunakan tiga jenis hibrida dalam sistem geraknya, yaitu hydrogen fuel cell, solar panel cell, dan mesin diesel. Tenaga penggeraknya berupa "a proton exchange membrane fuel cell" yang mengubah hidrogen menjadi listrik. "Solar Panels" akan mengumpulkan sinar matahari dan mengubahnya menjadi listrik. Juga kapal ini dilengkapi dengan mesin diesel. Mesin diesel, tenaga hidrogen dan solar panel akan digunakan secara bergantian dalam pengoperasiannya[5].

\section{METODOLOGI PENELITIAN}

Diagram alir (flowchart) metodologi dalam pengerjaan Jurnal ini dapat dilihat pada Gambar 5 dibawah ini.

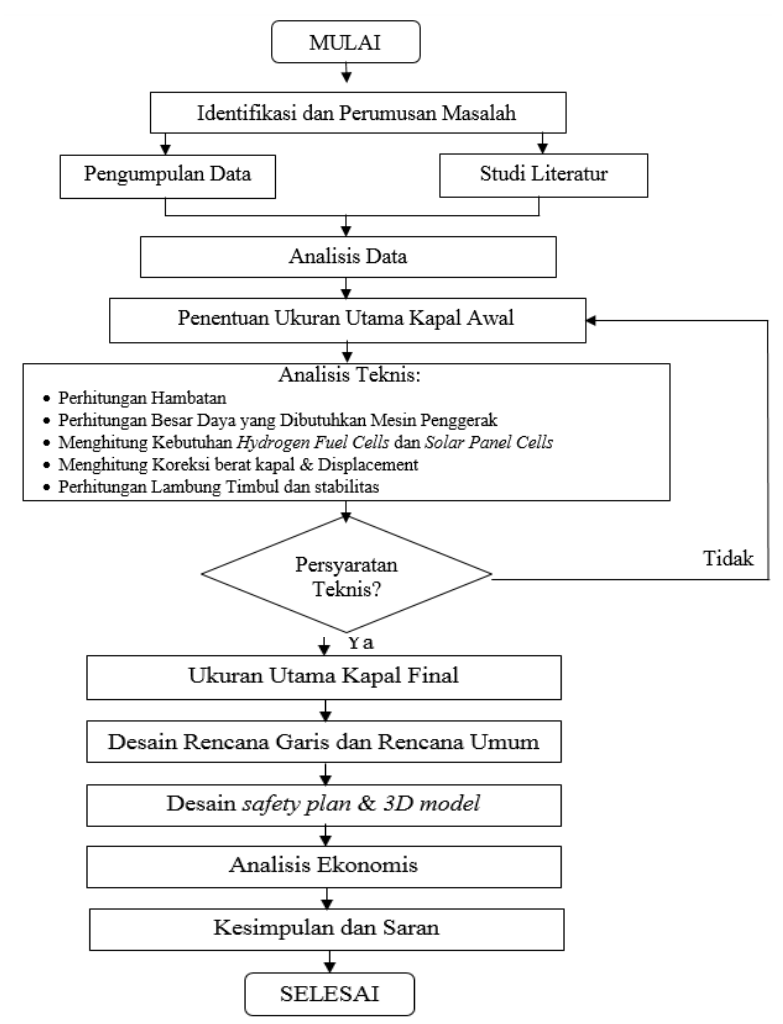

Gambar 5. Diagram alir 


\section{ANALISIS TEKNIS DAN PEMBAHASAN}

\section{A. Penentuan Payload}

Dalam penentuan ukuran utama kapal menggunakan metode forecasting jangka panjang untuk data terbaru. Adapun faktor-faktor yang digunakan dalam penentuan ukuran utama kapal yaitu jumlah pengguna jasa penyeberangan UjungKamal berupa penumpang, kendaraan dan bagasi.

Tabel 1.

Data Pengguna Jasa Ujung-Kamal

\begin{tabular}{cccccc}
\hline \hline & & \multicolumn{5}{c}{ Data Angkutan } \\
No & Tahun & Penumpang & Roda 2 & Roda 4 & Bagasi \\
\hline 1 & 2011 & $1,821,930$ & 791,146 & 104,105 & 52,631 \\
2 & 2012 & $1,519,187$ & 733,437 & 87,714 & 49,103 \\
3 & 2013 & $1,250,759$ & 726,677 & 92,727 & 48,069 \\
4 & 2014 & 929,024 & 666,315 & 96,920 & 44,841 \\
5 & 2015 & 713,258 & 638,897 & 83,123 & 46,851 \\
6 & 2016 & 404,580 & 599,808 & 83,090 & 43,552 \\
7 & 2017 & 123,829 & 562,646 & 79,815 & 41,970 \\
& & & & & \\
& Total & $6,762,566$ & $4,718,927$ & 627,494 & 327,018 \\
& Rata- & 966,081 & 674,132 & 89,642 & 46,717 \\
\hline \hline
\end{tabular}

Dari data angkutan rata-rata pertahun pada Tabel 1, selanjutnya akan dihitung rata-rata pengguna jasa penyeberangan Ujung-Kamal perhari. Untuk rencana operasionalnya dapat dilihat pada Tabel 2.

Tabel 2.

Perencanaan Operasional Kapal

\begin{tabular}{ccc}
\hline \hline Jumlah Kapal & 3 & unit \\
\hline \multirow{2}{*}{ Jam Operasional } & Buka & 5:00:00 AM \\
& Tutup & 8:00:00 PM \\
Perjalanan & 0.5 & jam/trip \\
1 kapal & 10 & trip/hari \\
\hline \hline
\end{tabular}

Pada Tabel 2 menunjukkan bahwa ada tiga unit kapal yang beroperasi di jalur penyeberangan Ujung-Kamal mulai dari jam 05.00-20.00 WIB. Dalam sehari, setiap kapal akan beroperasi sebanyak $10 \mathrm{kali}$, di mana dalam satu kali trip membutuhkan waktu selama 30 menit.

Jumlah penumpang per kapal untuk satu kali trip didapatkan dengan cara membagi nilai rata-rata penumpang dari tahun 2011-2017 dengan jumlah hari dalam satu tahun yaitu 365 hari. Pada Tabel 1 diketahui rata-rata penumpang/tahun adalah 966081 orang, sehingga rata-rata penumpang dalam sehari untuk satu kapal yaitu:

Rata-rata penumpang/tahun $=966081$

Rata-rata penumpang perhari $=966081: 365$ hari

$$
=2647 \text { penumpang }
$$

Selanjutnya dihitung jumlah penumpang per kapal untuk satu kali trip, di mana kapal yang beroperasi sebanyak unit unit dan setiap satu kapal melakukan sepuluh kali trip. Sehingga untuk satu kali trip, kapal bermuatan 88 penumpang. Dengan cara yang sama, maka didapatkan jumlah pengguna jasa untuk kendaraan roda dua, roda empat, dan bagasi.
Tabel 3.

Payload Luasan Deck

Perhitungan payload akhir didapat dari perhitungan luasan geladak penumpang dan kendaraan, di mana jumlah muatan

Perhitungan Payload Luasan Deck

\begin{tabular}{|c|c|c|c|c|c|}
\hline \multicolumn{2}{|c|}{ Jumlah komplemen } & \multicolumn{2}{|c|}{15} & \multicolumn{2}{|c|}{ Orang } \\
\hline \multicolumn{2}{|c|}{ Penumpang } & \multicolumn{2}{|c|}{90} & \multicolumn{2}{|c|}{ Orang } \\
\hline \multicolumn{2}{|c|}{ Penjaga Stand makanan } & \multicolumn{2}{|c|}{4} & \multicolumn{2}{|c|}{ Orang } \\
\hline Muatan & $\begin{array}{l}\text { Asumsi } \\
\text { Beban } \\
\text { (ton) }\end{array}$ & $\begin{array}{l}\text { Luas per } \\
\text { unit }(\mathrm{m} 2)\end{array}$ & $\begin{array}{c}\text { Berat } / \mathrm{m} \\
2\end{array}$ & $\begin{array}{c}\text { Luasan } \\
\text { Total } \\
\text { (m2) }\end{array}$ & $\begin{array}{l}\text { Berat } \\
\text { Total } \\
\text { (ton) }\end{array}$ \\
\hline Motor & 0.2 & 0.99 & 0.202 & 85.8 & 17.3333 \\
\hline Mobil & 5 & 4.5 & 1.111 & 33.3 & 37.0000 \\
\hline Truk & 40 & 15.3 & 2.614 & 30.6 & 80.0000 \\
\hline Penumpang & 0.075 & 0.16 & 0.469 & 14.4 & 6.7500 \\
\hline Crew & 0.075 & 0.16 & 0.469 & 2.4 & 1.1250 \\
\hline $\begin{array}{c}\text { Penjaga } \\
\text { stand }\end{array}$ & 0.075 & 0.16 & 0.469 & 0.64 & 0.3000 \\
\hline Bagasi & & & & & 4.2700 \\
\hline Barang pnp & 0.005 & & & & 0.4500 \\
\hline $\begin{array}{c}\text { Barang } \\
\text { crew }\end{array}$ & 0.005 & & & & 0.075 \\
\hline TOTA & PAYLOA & UASAN & $\mathrm{CK}$ & 167.14 & 147.3033 \\
\hline
\end{tabular}

yang diplot pada gambar menggunakan data perhitungan muatan pada Tabel 1. Tujuan menghitung payload luasan geladak yaitu untuk mencari berat per luasan $\mathrm{m}^{2}$. Sehingga didapatkan total payload luasan geladak sebesar 147,3033 ton ini dilakukan pembulatan keatas sebesar 2 digit. Jadi payload dari Kapal Motor Penyeberangan ini adalah 148 Ton.

\section{B. Penentuan Ukuran Utama}

Setelah didapatkan hasil nilai payload dari luasan geladak, selanjutnya digambar untuk pentaan kursi penumpang serta kendaraan di kapal. Ukuran standard kursi, jarak antar kursi, serta lebar akses jalan yang sudah disesuaikan dengan aturan Surat Dirjen Perhubungan Darat No. AP.005/3/13/DPRD/1994 [6].

Untuk penataan kendaraan dan pengikatan kendaraan di atas kapal sudah disesuaikan dengan aturan Keputusan Menteri Perhubungan 115 Tahun 2016 tentang Lashing [7].

Ukuran utama pada kapal ini ditentukan berdasarkan jumlah muatan dan disesuaikan dengan aturan penempatan kendaraan di atas kapal penyeberangan. Sehingga didapatkan ukuran utama kapal sebagai berikut:

$$
\begin{array}{llr}
\text { Lpp } & : 42 & \mathrm{~m} \\
\text { Lwl } & : 43.68 & \mathrm{~m} \\
\mathrm{~B} & : 6.9 & \mathrm{~m} \\
\mathrm{H} & : 3 & \mathrm{~m} \\
\mathrm{~T} & : 2 & \mathrm{~m}
\end{array}
$$

Ukuran utama tersebut kemudian disesuaikan dengan batasan-batasan perbandingan ukuran utama sebagai berikut:

$$
\begin{aligned}
& \mathrm{L} / \mathrm{B}=6.095 .3<\mathrm{L} / \mathrm{B}<8 \\
& \mathrm{~B} / \mathrm{T}=3.453 .2<\mathrm{B} / \mathrm{T}<4 \\
& \mathrm{~L} / \mathrm{T}=21.00 \quad 10<\mathrm{L} / \mathrm{T}<30 \\
& \mathrm{~L} / 16=2.63 \mathrm{H}>\mathrm{L} / 16
\end{aligned}
$$


Dari pengecekan batasan-batasan perbandingan ukuran utama tersebut dapat disimpulkan bahwa ukuran utama kapal memenuhi karena hasil perbandingan masuk dalam range yang telah ditentukan [8].

\section{Perhitungan Koefisien Bentuk Kapal}

Setelah didapatkan ukuran utama kapal, langkah selanjutnya yang dilakukan adalah melakukan perhitungan awal. Perhitungan awal meliputi perhitungan froud number, perhitungan coefficient $(\mathrm{Cb}, \mathrm{Cm}, \mathrm{Cp}$, dan Cwp) serta displacement.

D. Perhitungan Coefficient Ukuran Utama Kapal

$$
\begin{array}{ll}
\mathrm{Fn} & =0.248 \\
\mathrm{Cb} & =0.637 \\
\mathrm{Cm} & =0.98 \\
\nabla & =383.97 \mathrm{~m}^{3} \\
\Delta & =393.56 \mathrm{ton}
\end{array}
$$

\section{E. Perhitungan Hambatan dan Propulsi}

Perhitungan hambatan total dilakukan dengan metode Holtrop sehingga menghasilkan nilai hambatan sebagai berikut.

Tabel 4.

\begin{tabular}{ccc}
\multicolumn{3}{c}{ Hambatan Kapal dan propulsi } \\
\hline \hline \multicolumn{3}{c}{ Rekap Hambatan dan Propulsi } \\
\hline Rt & 17.143 & $\mathrm{kN}$ \\
EHP & 88.18 & $\mathrm{~kW}$ \\
DHP & 147.579 & $\mathrm{~kW}$ \\
BHP & 176.714 & $\mathrm{~kW}$ \\
\hline \hline
\end{tabular}

\section{F. Pemilihan Mesin Induk}

Mesin induk yang digunakan pada Kapal Motor Penyeberangan dapat dilihat pada Tabel 5.

$$
\text { Tabel } 5 .
$$

Spesifikasi Mesin Induk

\begin{tabular}{ccc}
\hline \multicolumn{3}{c}{ Mesin Induk } \\
\hline Tipe & 6NY16-UT & YANMAR \\
Daya & 331 & $\mathrm{~kW}$ \\
RPM & 1350 & $\mathrm{rpm}$ \\
Berat & 2880 & $\mathrm{~kg}$ \\
\hline \hline
\end{tabular}

\section{G. Perhitungan Berat Kapal}

Berat kapal terdiri dari 2 komponen, yaitu komponen DWT (dead Weight tonnage) dan komponen LWT (Light Weight tonnage).

Tabel 6.

\begin{tabular}{ccc} 
& \multicolumn{2}{c}{ Total Berat DWT dan LWT } \\
\hline \hline DWT & 148.475 & ton \\
\hline LWT & 227.202 & Ton \\
Berat & 375.676 & ton \\
Displasemen & 393.56 & ton \\
Selisih & 17.89 & ton \\
Margin & $4.5 \%$ & \\
\hline \hline
\end{tabular}

\section{H. Perhitungan Titik Berat Kapal}

Perhitungan titik Berat Kapal terdiri dari titik berat DWT dan titik berat LWT.

\section{Perhitungan Freeboard}

Kapal Motor Penyeberangan dengan panjang kurang dari 500 GT, maka harus menggunakan aturan Non-Convention Vessel Standart (NCVS) Indonesian Flagged yang dikeluarkan oleh Kementrian Perhubungan Republik Indonesia. Berikut ini adalah input awal yang diperlukan untuk menghitung freeboard. [8].

Berikut ini adalah hasil perhitungan freeboard Tabel 7.

Tabel 7.

Hasil Perhitungan Freeboard

\begin{tabular}{cll}
\hline \hline Lambung Timbul & \multicolumn{1}{c}{ Nilai } & Satuan \\
\hline Lambung Timbul yang Syaratkan & 0.15 & $\mathrm{~m}$ \\
Lambung Timbul Sebenarnya & 1.0 & $\mathrm{~m}$ \\
Kondisi & diterima & \\
\hline \hline
\end{tabular}

\section{J. Perhitungan Trim}

Dengan menggunakan kriteria NCVS, di mana trim kapal tidak boleh melebihi nilai Lpp/50. Untuk hasil nilai trim dapat dilihat pada Tabel 8 .

Tabel 8.

Nilai Trim

\begin{tabular}{ccccl}
\hline \hline No & Kondisi & Batasan & Nilai & Status \\
\hline 1 & Loadcase 1 & 0.84 & 0.64 & Diterima \\
2 & Loadcase 2 & 0.84 & 0.796 & Diterima \\
3 & Loadcase 3 & 0.84 & 0.813 & Diterima \\
4 & Loadcase 4 & 0.84 & 0.688 & Diterima \\
5 & Loadcase 5 & 0.84 & 0.446 & Diterima \\
6 & Loadcase 6 & 0.84 & 0.795 & Diterima \\
\hline \hline
\end{tabular}

\section{K. Perhitungan Stabilitas}

Kriteria kondisi pemuatan (loadcase) yang digunakan pada perhitungan ini mengacu pada Intact Stability (IS) Code Ch. III/3.5 [9].

Tabel 9.

Perhitungan Stabilitas

\begin{tabular}{ccccccc}
\hline \hline Data & $\mathrm{e}_{0-30^{\circ}}$ & $\mathrm{e}_{0-40^{\circ}}$ & $\mathrm{e}_{30-40^{\circ}}$ & $\mathrm{h}_{30^{\circ}}$ & $\theta_{\max }$ & $\mathrm{GM}_{0}$ \\
\hline LC 1 & 21.49 & 38.34 & 16.845 & 3.174 & 82.7 & 2.738 \\
LC 2 & 20.22 & 36.09 & 15.87 & 3.091 & 84.5 & 2.584 \\
LC 3 & 21.06 & 37.56 & 16.49 & 3.11 & 82.7 & 2.68 \\
LC 4 & 23.07 & 40.28 & 17.21 & 3.313 & 87.3 & 2.969 \\
LC 5 & 21.19 & 37.6 & 16.4 & 3.176 & 84.5 & 2.711 \\
LC 6 & 23.97 & 42.03 & 18.054 & 3.3 & 84.5 & 3.061 \\
Criteria & $\geq$ & $\geq$ & $\geq$ & & & \\
Intact & 3,151 & 5,1566 & 1,7189 & $\geq 0,2$ & $\geq 25$ & $\geq 0,15$ \\
Stability & & & & & \\
Kondisi & OK & OK & OK & OK & OK & OK \\
\hline \hline
\end{tabular}

KMP TWINS merupakan tipe kapal yang mengangkut kendaraan beserta muatannya dan penumpang. Sehingga kondisi pemuatannya sama dengan kapal penumpang barang. Kondisi pemuatan untuk kapal penumpang barang adalah sebagai berikut:

\section{Pembuatan Rencana Garis}

Setelah semua perhitungan selesai, langkah selanjutnya adalah pembuatan Rencana Garis atau Lines Plan. 


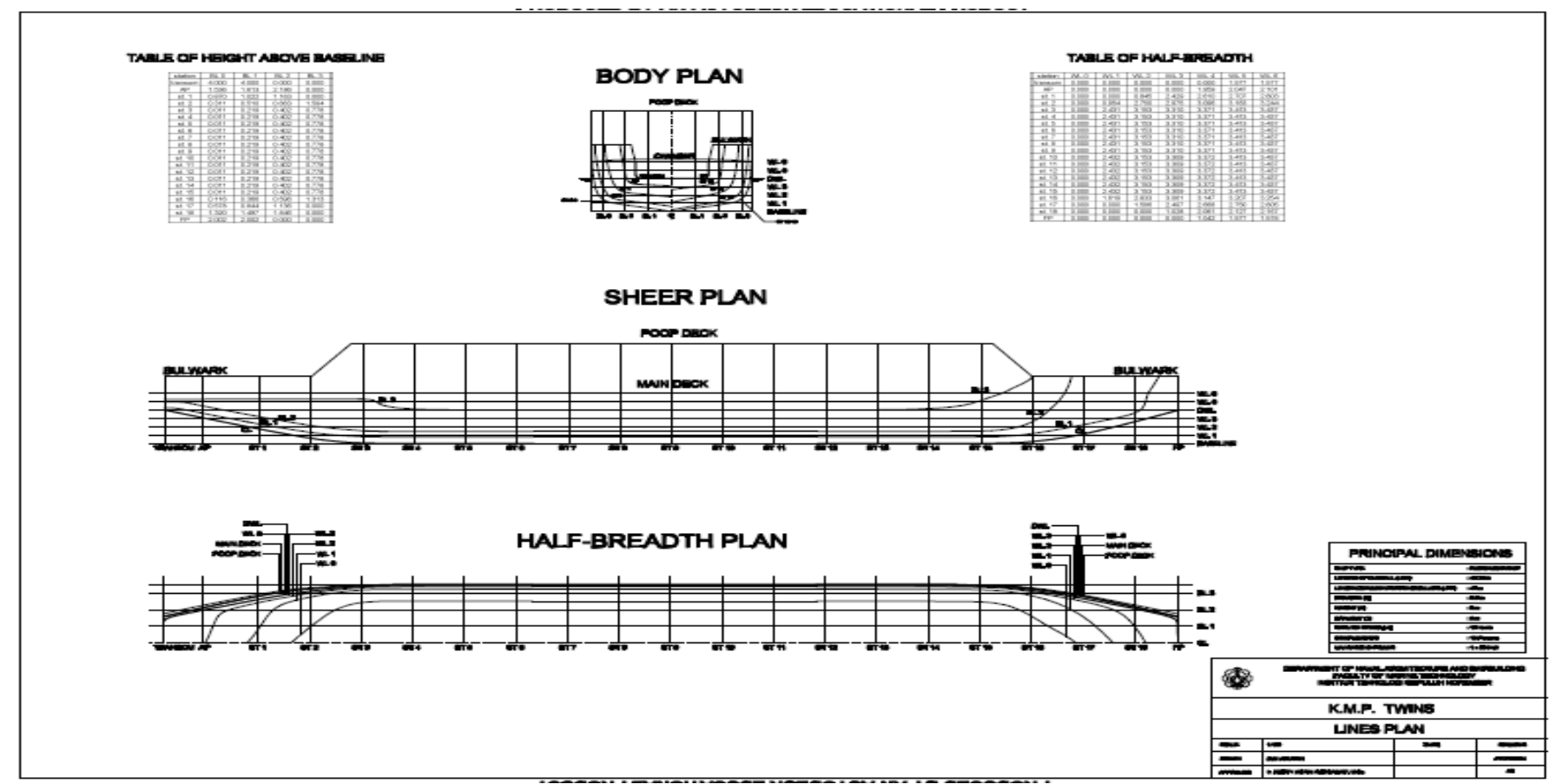

Gambar 6. Lines Plan

\section{Pembuatan Rencana Umum}

Penyusunan rencana umum merupakan suatu proses bertahap yang disusun dari percobaan, dan pengecekan, sepertipada Gambar 7.

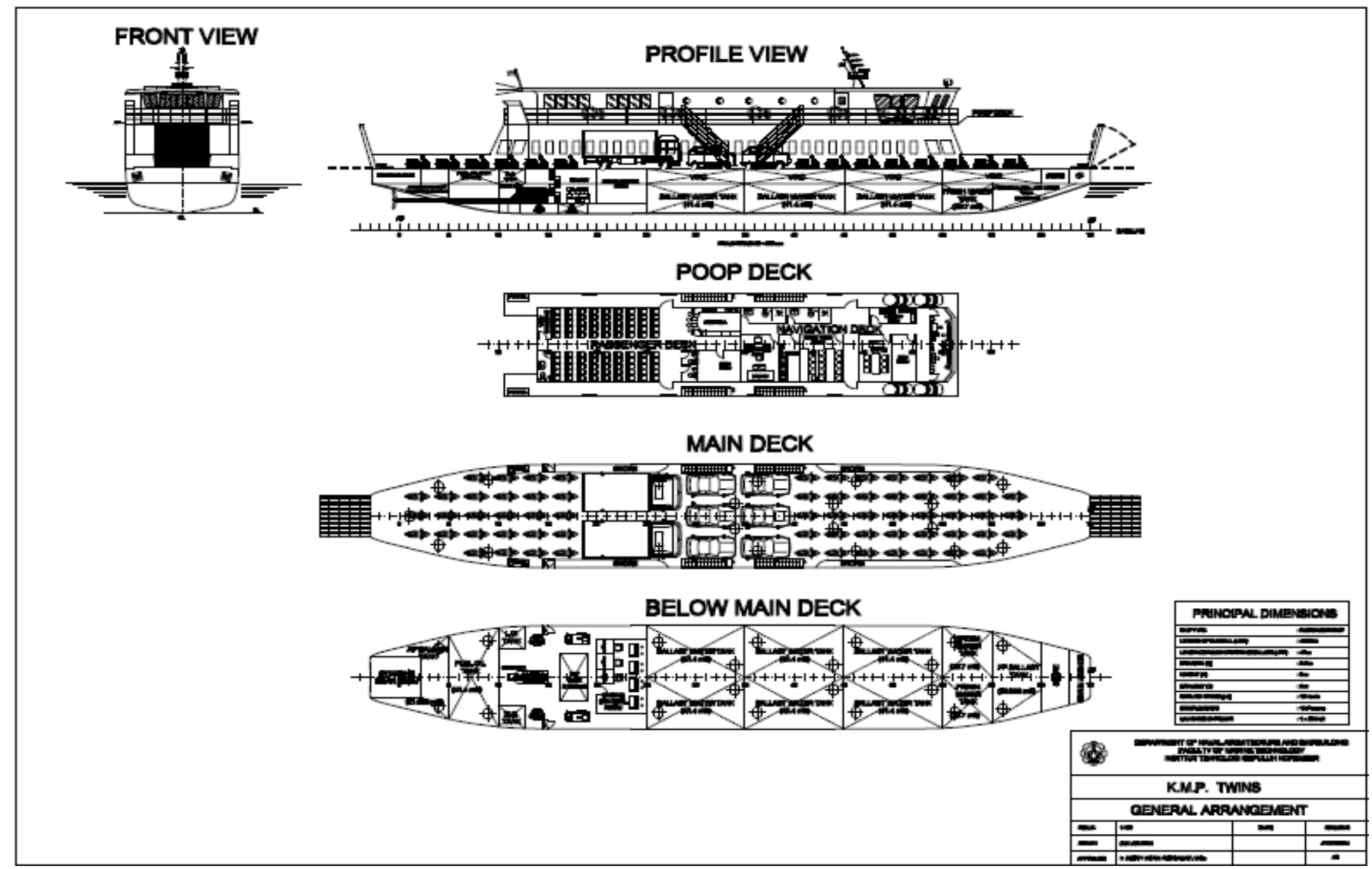

Gambar 7. General Arrangement 


\section{N. Gambar 3D}



Gamba 8. 3D Kapal Motor Penyeberangan

Pada Gambar 8 menunjukkan gambar kapal tampak samping, ruang geladak penumpang, serta geladak kendaraan.

\section{ANALISIS EKONOMIS}

\section{A. Biaya Pembangunan}

Biaya pembangunan kapal terdiri dari weight cost (biaya baja kapal, peralatan dan perlengkapan, serta permesinan kapal) dan non weight cost serta koreksi biaya pembangunan. Setelah dihitung didapatkan biaya pembangunan sebesar Rp 13,173,344,991.91 dengan nilai tukar USD terhadap Rupiah senilai Rp 13.364 pada 16 Juni 2017.

\section{B. Biaya Operasional}

Biaya operasional Kapal Motor Penyeberangan sebesar Rp 2,402,574,008 per tahun.

\section{Estimasi Keuntungan dan BEP}

Keuntungan bersih per tahun sebesar Rp 194,982,863.52 dengan waktu balik modal pada bulan ke-68 atau tahun ke-6.

\section{Harga Tiket Penyeberangan}

Harga tiket kapal hibrida lebih murah 30\% dari kapal penyeberangan yang sudah beroperasi di Ujung-Kamal. Di mana nilai investasi keuntungan sebesar $13 \%$.

\section{KESIMPULAN}

Setelah dilakukan percobaan dan penelitian maka kesimpulan dari Jurnal ini adalah sebagai berikut:

1. Penentuan ukuran utama KMP TWINS berdasarkan jumlah pengguna jasa dari Penyeberangan Ujung-Kamal. Dari data tersebut, kemudian dibuat layout awal dan didapatkan payload 148 Ton.

Ukuran Utama KMP TWINS yang didesain yaitu:

- $\operatorname{Lpp}($ Panjang) $=42 \mathrm{~m}$

- $\mathrm{B}$ (Lebar) $\quad=6.9 \mathrm{~m}$

- $\mathrm{H}$ (Tinggi) $=3 \mathrm{~m}$

- $\mathrm{T}$ (Sarat) $=2 \mathrm{~m}$

2. Desain Kapal Motor Penyeberangan dengan sistem penggerak hibrida untuk rute Ujung Surabaya-Kamal Bangkalan bisa menghemat konsumsi bahan bakar, di mana kebutuhan gas $\mathrm{H}_{2}$ per trip adalah $0.09 \mathrm{~kg} /$ trip $(1 \mathrm{~kg}$ gas hidrogen dengan isi $40 \mathrm{~L}$ bisa untuk pemakaian 11 kali trip) serta tidak menimbulkan emisi gas buang pada saat pemakain bahan bakar hidogen. Sedangkan 54 unit panel surya dapat menghasilkan daya listrik sebesar $18 \mathrm{~kW}$ dengan waktu pengecasan baterai selama 3 jam sehingga menghasilkan daya listrik total sebesar $54 \mathrm{kWh}$ yang dapat digunakan untuk memenuhi kebutuhan listrik di kapal untuk 2 kali trip.

3. Desain Lines Plan, General Arrangement, Safety Plan, dan 3D Model telah dibuat.

4. Berdasarkan Analisis Ekonomis yang dilakukan, didapatkan biaya investasi pembangunan KMP TWINS sebesar Rp 13,173,344,991.91. Nilai investasi kelayakan pembangunan kapal sebesar 13\% dengan harga tiket 30\% lebih murah dibandingkan dengan Kapal Motor Penyeberangan yang sudah beroperasi di Ujung-Kamal.

\section{UCAPAN TERIMA KASIH}

Penulis mengucapkan terima kasih kepada PT. Angkutan Sungai Danau dan Penyeberangan (ASDP) Cabang Surabaya yang telah memberikan data angkutan di Penyeberangan Ujung-Kamal.

\section{DAFTAR PUSTAKA}

[1] K. Keuangan, "Menggagas Pajak Emisi Gas Buang," 2015. [Online]. Available: http://www.kemenkeu.go.id/Artikel/menggagas-pajak-emisi-gasbuang.

[2] F. Rohmadhana, "Analisis Teknis dan Ekonomis Konversi Landing Craft Tank (LCT) Menjadi Kapal Motor Penyeberangan (KMP) Tipe Ro-ro untuk Rute Ketapang (Kabupaten Banyuwangi) Gilimanuk (Kabupaten Jembrana)," Publ. Ilm. Online Mhs. ITS, vol. 5, no. 2, 2016.

[3] H. A. Kurniawati, Statutory Regulation. Surabaya, 2013.

[4] P. N. 29, Lampiran VI MARPOL 73/78 Peraturan Tentang Pencegahan Pencemaran Udara dari Kapal. 2012.

[5] L. Prasetyo, "Desain Eco-Friendly Boat Dengan Sumber Energi Hydrogen Fuel Cell Untuk Wisata Kali Mas Surabaya," Publ. Ilm. Online Mhs. ITS, vol. 4, no. 2, 2015.

[6] D. P. Darat, Surat Keputusan Dirjen Perhubungan Darat. No. AP.005/3/13/DPRD/1994. 1994.

[7] M. Pehubungan, Peraturan Menteri Perhubungan Republik Indonesia No 115 "Tatacara Pengangkutan Kendaraan di Atas Kapal." 2016.

[8] E. V Lewis, Principle of Naval Architecture (2nd ed., Vol. 2). Jersey: SNAME, 1988.

[9] IMO and I. Resolution, Intact Stability (IS) Code-Intact Stability for All Types of Ships. 